\title{
Peertechz
}

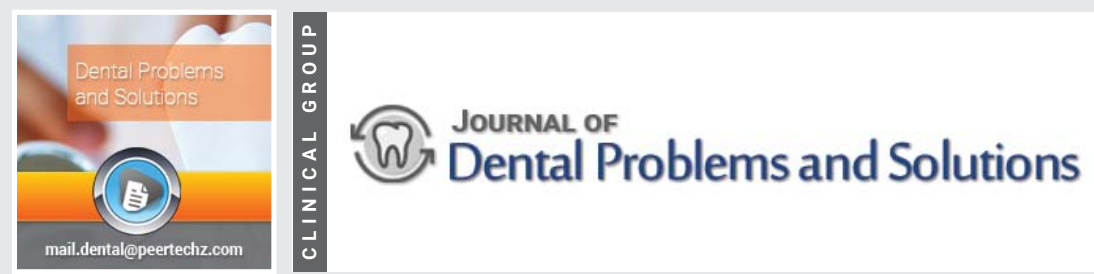

SSN: $2394-8418$

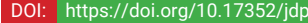

Received: 30 November, 2020

Accepted: 07 December, 2020

Review Article

\section{Role of Irrigants in Endodontics}

Published: 09 December, 2020

*Corresponding author: Dr. Prabjot Kaur, Department of Conservative Dentistry and Endodontics, Desh Bhagat Dental College and Hospital, Mandi Gobindgarh, Punjab, India, E-mail: Mediteon20@gamil.com

\section{Prabjot Kaur*}

Lecturer, Department of Conservative Dentistry and Endodontics, Desh Bhagat Dental College and ORCID: https://orcid.org/0000-0001-7870-9552 Keywords: Endodontic irrigation; NAOCL; $\mathrm{CHX} ; \mathrm{H}_{2} \mathrm{O}_{2}$; MTAD; EDTA

Hospital, Mandi Gobindgarh, Punjab, India

https://www.peertechz.com

Check for updates

\section{Abstract}

Irrigation is a key part of successful root canal treatment as it fulfils several important mechanical, chemical and (micro) biological functions including the healing of periapical tissues. It is the only way to reach and impact those areas of the root canal wall which are not touched by mechanical instrumentation. The initial and primary endodontic treatment (rootcanal treatment) goal must be to optimize root canal disinfection and to prevent reinfection. All over the years many materials have been used to serve as endodontic irrigants particularly sodium hypochloride and EDTA. However there are also other solutions available which can be used for the purpose of irrigation. So, in this article we will narrate different types of irrigating solutions with their specifics, requirements, which can be used in future endodontic practice, and their advantages and limitations.

\section{Introduction}

The main cause of pulpal and periapical diseases are different living and nonliving irritants. Then onliving irritants include the mechanical, thermal and chemical irritants. The living irritants include different types of microorganisms such as bacteria, yeasts and viruses. When different pathological changes start to occur within dental pulp, the space within canal of root acquires the calibrerto harbour irritants including various species of bacteria, their toxins and byproducts. Investigations in animals and patients have shown that pulpal and/or periradicular diseases cannot develop without the presence of bacteria $[1,2]$. The greater test for irrigation might be the regions immaculate by the files, for example, fins, isthmuses and enormous lateral canals [3]. Additionally, enormous territories in the oval and flat canals may remain untouched notwithstanding careful instrumentation and those zones contain tissue leftovers and biofilms that just can be taken out by substance implies utilizing irrigation system. The apical root canal poses a specific challenge to irrigation as the balance between safety and effectiveness is particularly important in this area.

There is no single irrigating solution that alone sufficiently covers all of the functions required from an irrigant. Optimal irrigation is based on the combined use of 2 or several irrigating solutions, in a specific sequence, to predictably obtain the goals of safe and effective irrigation. Irrigants have traditionally been delivered into the root-canal space using syringes and metal needles of different size and tip design [4]. Clinical experience and research have shown, however, that the classic approach typically results in ineffective irrigation, particularly in peripheral areas such as anastomoses between canals, fins, and the most apical part of the main root canal. Therefore, many of the compounds used for irrigation have been chemically modified and several mechanical devices have been developed to improve the penetration and effectiveness of irrigation. This article summarizes the chemistry, biology, and procedures for safe and efficient irrigation and provides cutting-edge information on the most recent developments [4]. So, every effort should be made to eradicate infections during the root canal treatment. Thus in this paper we will discuss about the pros and cons of various endodontic irrigants.

\section{Goals of irrigation}

Irrigation has a central role in endodontic treatment. During and after the process of instrumentation, the irrigants administers the removal of microorganisms, tissue remnants, and dentin chips from the root canal through a flushing mechanism. Different irrigants can help prevent packing of the hard and soft tissue in the apical root canal and extrusion of 
infected material into the periapical area. Most of the irrigants dissolve organic or inorganic tissue within the root canal. Besides, different other irrigating solutions have antimicrobial action and effectively and decimate microbes and yeasts when presented in direct contact with the microorganisms. A few irrigating system likewise have cytotoxic potential, and they can cause serious torment in the event that they obtain entrance into the periapical tissues. Utilizing a blend of irrigants in the right grouping adds to a fruitful treatment outcome [5].

\section{Classification [6]}

Based on mechanism of action the irrigantsare classified into nonbactericidal and bactericidal irrigants.

Non bactericidal irrigants

- $\quad$ Saline

- Local anesthetics

- Distilledwater.

\section{Bactericidal irrigants}

- Sodium hypochlorite ( with $0.5 \%, 1 \%, 1.5 \%, 2.5 \%$, $5.25 \%$, and $6 \%$ concentrations)

- Chlorhexidine (CHX) (2\%)

- Iodine

- Hydrogen peroxide $\left(\mathrm{H}_{2} \mathrm{O}_{2}\right)(3 \%)$.

Chelatorsolutions

- $\quad$ Ethylene diamine tetra acetic acid (EDTA, 17\%)

- $\quad$ Citric acid $(10-50 \%)$

- $\quad$ Mixture of tetracycline, acid and detergent(MTAD)

- Tetraclean

- $\quad$ Maleicacid.

Herbal irrigants

- Electronically activated water(EAW)

Bis-dequalinium acetate (BDA)

- $\quad$ Photo-activated disinfection(PAD)

- Ozone

- Laser

\section{Different types of irrigating solutions}

Sodiumhypochlorite: The American Endodontics Association has defined it as yellowish-green, pale, extremely alkaline liquid, with strong scent similar to chlorine. It exerts dissolving action against organic remains and necrotic tissue and has additionally a powerful anti-microbial adequacy, Dakin presented sodium hypochlorite arrangement during 1915, in World
War I utilized for purification of open or contaminated injuries, later in 1917, Barret spread the utilization of Dakin arrangement in dentistry, especially for root canal irrigation system. Dr. Blass was one among the pioneers who utilized $5 \%$ sodium hypochlorite (chlorinated soda) as organic solvent and a potent germicide.

The usage of $5 \%$ sodium hypochlorite for preparation of root canal in tooth with necrotic pulps was described by Walker. Lewis in 1954, focussed on the use of sodium hypochlorite with commercial brand- name Clorox, due to the fact that this product contained $5.25 \%$ available chlorine concentration. Shih in 1970 studied in vitro antibacterial action of $5.25 \%$ sodium hypochlorite on E. faecalis and S. Aureus $[7,8]$.

\section{Mechanism of action}

Scheme 1: Saponification reaction.

O

O

II II

$\mathrm{R}-\mathrm{C}-\mathrm{O}-\mathrm{R}+\mathrm{NaOH} \leftrightarrow \mathrm{R}-\mathrm{C}-\mathrm{O}-\mathrm{Na}+\mathrm{R}-\mathrm{OH}$

Fattyacid Sodiumhydroxide Soap Glycerol

Scheme 2: Amino acid neutralizationreaction.

$\begin{array}{llll}\mathrm{H} & \mathrm{O} & \mathrm{H} & \mathrm{O}\end{array}$

I $/ / / / /$

$\mathrm{R}-\mathrm{C}-\mathrm{O}-\mathrm{C}+\mathrm{NaOH} \leftrightarrow \mathrm{R}-\mathrm{C}-\mathrm{O}-\mathrm{C}+\mathrm{H}_{2} \mathrm{O}$

II

$\mathrm{NH}_{2} \quad \mathrm{OH} \quad \mathrm{NH}_{2} \quad \mathrm{ONa}$

Aminoacid Sodium hydroxide Salt Water

Scheme 3: Chloramination reaction.

$\begin{array}{lll}\mathrm{H} & \mathrm{O} & \mathrm{Cl} \mathrm{O} \\ \mathrm{I} & / / & \mathrm{I}\end{array}$

$\mathrm{R}-\mathrm{C}-\mathrm{O}-\mathrm{C}-\mathrm{HOCl} \leftrightarrow \mathrm{R}-\mathrm{C}-\mathrm{O}-\mathrm{C}+$ $\mathrm{H} 2 \mathrm{O}$

II

$\mathrm{NH}_{2} \mathrm{OH} \quad \mathrm{NH}_{2} \quad \mathrm{OH}$

Aminoacid Hypochlorousacid Chloramine Water

The above three schemes of reactions that occur in the presence of microorganisms and organic tissue lead to the antimicrobial effect and tissue dissolution process.

Temperature: Various studies have showed that temperature rise of $25^{\circ} \mathrm{C}$ increased $\mathrm{NaOCl}$ efficacy by 100 times. It suggest that the capacity of $1 \%$ of $\mathrm{NaOCl}$ at $45^{\circ} \mathrm{C}$ to dissolve pulp tissue is found to be equal to that of a $5.25 \%$ of the solution at $20^{\circ} \mathrm{C}$.

\section{Ultrasonic agitation}

This procedure uses mostly ISO no. 15 in canals filled with 
sodium chloride which lead to the development of ultrasonic energy and warms the solution in the canal. The vibrations cause movement of aqueoussodium hypochloride into the ramifications in the canal, this effect is called as "acoustic streaming. Use of fresh solution: Freshly prepared solutions have effective antimicrobial and tissue dissolving capacity. Increasing the duration and volume of the irrigation.

Sodium hypochlorite solution is virucidal and sporicidal and show higher tissue dissolving effects on necrotic tissues than vital tissues. There has been a controversy over the concentration of this solution to be used as an irrigant in endodontic procedures. This solution in higher concentrations has a higher tissue-dissolving capability, but even in lesser concentrations but in high volumes, can be equally effective. Based on the currently available evidence, there is no rationale for using hypochlorite solutions at concentrations over 1\% wt/ vol [11]. Drawbacks are its cytotoxicity when injected into periradicular tissues, itstaste, foul smell, ability to bleach clothes and cause corrosion of metal objects. Besides, it doesn't kill all microbes and doesn't totally eliminate the entirety of the smear layer; it likewisealters the properties of dentin. The greater parts of the mishaps because of $\mathrm{NaOCl}$ are a direct result of inaccurate assurance of endodontic working length, lateral perforation, iatrogenic widening of the apical foramen, or wedging of the irrigating needle. Unmistakably, all safety measures must be attempted to forestall such mishap $[12,13]$

\section{Adverse effect}

Recently, it has been shown by in vitro studies that longterm exposure of dentin to a high concentration sodium hypochlorite can have a detrimental effect on dentin elasticity and flexural strength. Although there are no clinical data on this phenomenon, it raises the question of whether hypochlorite in some situations may increase the risk of vertical root fracture $[12,13]$.

\section{Edta (Ethylenediamine Tetraacetic Acid)}

Complete cleaning of the root canal requires the combined use of organic and inorganic tissue- dissolving irrigants. As $\mathrm{NaOCl}$ viably breaks down only organic tissue, other irrigants should be utilized to eliminate debris and the smear layer. The use of demineralizing agent like EDTA as auxiliary solutions during RCT is recommended. Alfred Werner 1893 developed an idea of coordination compounds which today are referred as chelates. He created the process by which metals bind to organic molecules, which is the basic for chelation chemistry. Germany developed its own chelating material in the mid 1930 's. The synthetic substance they invented was EDTA (Ethylene-diamine-tetra-acetate). Different chelating agents were brought into endodontics as a guide for the preparation of narrow and calcified root canals [14]. Nowadays, EDTA is mainly synthesized from ethylenediamine (1,2-diaminoethane), formaldehyde (methanal), andsodiumcyanide [15]. This irrigant removes bacterial surface proteins by combining with metal ions from the cell envelope leading to bacterial death. When all available ions have been bound no further dissolution takes place, thus is self-limiting [14]. The addition of a quaternary ammonium bromide i.e. Cetavlon which increases the action of EDTA by decreasing its surface tension. This combination is called EDTAC which is effective in removal of smear layer and increasing the diameter of opened dentintubules [16].

\section{CHX (Chlorhexidinedigluconate)}

CHX is antimicrobial, and this effect is due to its positive charge, which is attracted to the negatively charged bacterial cell wall and increases the permeability of bacterial contents. It is bacteriostatic at low concentrations and at higher concentrations, it bactericidal and thus is effective against Gram-positive microbes and due to this reason it can be used in retreatment cases. Various in vivo and invitro studies have shown that it can be used against C. albicans and E. faecalis. In higher concentrations it causes extensive bacterial cell damage, coagulation of cytoplasm, and precipitation of proteins and nucleic acids. It shows increased antimicrobial activity against various pathogens like Staphylococcus aureus, Porphyromonasendodontalis, Prevotellaintermedia, E. faecalis, C. albicans, and Streptococcus mutants. It can be used either in liquid or gel forms. Its gel formulation makes the instrumentation easier which in turn reduces the smear layer formation better than the liquid formulation. As a result of cationic nature of the CHX molecule, it can be adsorbed by the hydroxyapatite and the teeth. At concentrations $>0.02 \%$, a layer of CHX is formed on the tooth surface which may reduce or prevent bacterial colonization. According to Rosenthal et al.substantivity of $2 \%$ CHX solution within the root canal is present after $10 \mathrm{~min}$ of application $[17,18]$.

\section{MTAD (Mixture of Tetracycline, Acid Anddetergent)}

It was introduced as an alternative to EDTA by Torabinejad, et al. in order to remove smear layer. It is a combination of $3 \%$ doxycycline, $4.25 \%$ citric acid and detergent-Tween 80 . It has a combined antibacterial chelating properties, however, its antibacterial activity might be inhibited by the buffering effect of dentin and the serum albumin which present in the root canal. The mechanism of action is completed when, the CA removes the smear layer that allows the doxycycline to enter the dentinal tubules and cause an antibacterial effect. It is advised that an initial irrigation for 20 min with $1.3 \% \mathrm{NaOCl}$ should be done then it should be followed by a 5 -min final rinse with MTAD. The disadvantage is that they do not dissolve organic tissue and are thus uses at the end of chemomechanical preparation following sodium hypochloride $[19,20]$.

\section{$\mathrm{H}_{2} \mathrm{O}_{2}$ (Hydrogenperoxide)}

It is a clear odourless liquid and has been widely used in dentistry. It is highly unstable compound that decomposes by heat and light. It's mechanism of action is completed by therelease of nascent oxygen which when coming in contact with tissue enzymes produces bactericidal effect by interfering with bacterial metabolism. Also the rapid release of nascent oxygen creates bubbling action which is said to aid in mechanical debridement by removing necrotic tissue and dentinal debris. However higher concentrations of hydrogen 
peroxide is toxic to the tissues, concentrations from $1-30 \%$ are being used in dentistry and only $3-5 \%$ is preferred for endodontic treatments. Its combination with $\mathrm{NaOCl}$ have been proven to be less effective as irrigating solutions as compared to whenused individually, due to a chemical reaction that results in the release of oxygen. The disadvatage of rapid nascent oxygen production can also be a complication when it reacts with blood and pulp debris and causes a pressure build up which may result in severe pain $[21,22]$.

\section{lodinecompounds}

These are bactericidal,virucidal, fungicidal, tuberculocidal and sporicidal. Mostly $2 \%$ iodine in $4 \%$ potassium iodide (IPI) has been used in endodontics. This combination has shown low toxicity and has a decreased tendency to stain dentine. The main advantage of Iodine is that $2 \%$ of preparations have shown to be lesspoisonous, less irritating and rapidly reduces the bacterial load than Formocresol, Camphorated Monochlorophenol (FMCP) and Cresatin.

Despite its antimicrobial effect, iodine is a highly potent allergen thereby increasing a risk for allergic reactions [23].

\section{Citric Acid (CA)}

It is easily available in the market and is used in concentrations ranging from $1 \%$ to $50 \%$. Few studies suggested the use of $10 \%$ citric acid as a final irrigation solution which yielded very good results in terms of smear layer removal. It has shown slightly better performance than EDTA at similar concentrations, although both solutions are highly effective in removing the smear layer from root canal walls. Various studies have showed the cytotoxicity of different chelators and in comparison $10 \%$ citric acid solution had proven to be more biocompatible than $17 \%$ EDTA . In other study, a $25 \%$ CA solution failed to destroy Enterococcus faecalis biofilms $[24,25]$.

\section{Maleic Acid (MA)}

MA is a mild organic acid which is used to roughen the surfaces of enamel and dentin in adhesive dentistry. It functions by removing the smear layer effectively at concentrations of $5 \%$ and $7 \%$. Additionally, when used at concentrations of $10 \%$ or higher, it causes demineralization and erosion of the root canal wall. A study done by Ballal et al.provedthat $7 \%$ malic acid application for 1 minute as final irrigant removed smear layer more effectively than 1 minute irrigation with $17 \%$ EDTA in the apical third canal. However, before theendodontic use, the effects of it on periapical tissues,appropriate usage techniques must be investigated [26,27].

\section{Tetraclean}

It is similar to MTAD, the difference is due to the addition of doxycycline- $50 \mathrm{mg} / \mathrm{ml}$ and a detergent (polypropylene glycol). It is effective against both facultative and anaerobic bacteria.

And removes the smear layer and opens up the dentinal tubule orifices. It shows low surface tension that allows the better penetration of the solution into the dentinal tubule. Various in-vitro studies have proved that Tetraclean is more efficient than MTAD against E. Faecalis [28,29].

\section{Herbalirrigants [30]}

Triphala: It consists of dried and powdered fruits of three medicinal plants. Terminaliabellerica,Emblicaofficinalis and Terminaliachebula. This combination achieved $100 \%$ killing of E. faecalis at $6 \mathrm{~min}$. Triphala contains fruits that are rich in citric acid, which aids in removal of the smear layer.

Green tea: It's polyphenols showed a statistically significant antibacterial activity against E. faecalis biofilm formed on tooth substrate. It also takes $6 \mathrm{~min}$ to achieve $100 \%$ killing of E. faecalis.

\section{Morinda Citrifoliajuice}

MCJ has wide range of therapeutic effects such as antibacterial, antifungal,antiviral,analgesic, antitumor, antihelmintic, anti-inflammatory, hypotensive, and immune-enhancing effects. It is biocompatible antioxidant which do not cause severe injuries to patients as can be caused by $\mathrm{NaOCl}$ accidents.

\section{Conclusion}

Irrigation and instrumentation are the most important and key parts of root canal treatment. Irrigation has several functions, the most important of which is to dissolve tissue and to have an antimicrobial effect. Apical irrigation poses a special challenge with regard to safety and effectiveness. Small, -gauge side-vented needles or negative pressure irrigation with $\mathrm{NaOCl}$ and EDTA in the apical canal will give the best results in this important area. Moreover in future various in vivo and in vitro studies of irrigants should emphasize on the production of a single solution that has tissue-solubilizing properties, is biocompatible, removes the smear layer, and has antibacterial effects.

\section{Prospective}

Irrigation has a key role in successful endodontic treatment. Although hypochlorite is the most important irrigating solution, no single irrigant can accomplish all the tasks required by irrigation. Detailed understanding of the mode of action of various solutions is important for optimal irrigation. New developments such as CFD and mechanical devices will help to advance safe and effective irrigation.

\section{References}

1. Kakehashi S, Stanley HR, Fitzgerald RJ (1965) The effects of surgical exposures of dental pulps in germ-free and conventional laboratory rats. Oral Surg Oral Med Oral Pathol 20: 340-349. Link: https://bit.ly/37GabTp

2. Sundqvist G (1976) Bacteriological studies of necrotic dental pulps UmeåUniversity Odontol Dissertation, No 7. University of Umeå, Sweden. Link: https://bit.ly/3mSkLwX

3. Haapasalo M, Shen Y, Qian W, Gao Y (2010) Irrigation in endodontics. Dent Clin North Am 54: 291-312. Link: https://bit.ly/37EHVQU 
4. Park E, Shen Y, Khakpour M, Haapasalo M (2013) Apical pressure and extent of irrigant flow beyond the needle tip during positive-pressure irrigation in an in vitro root canal model. J Endod 39: 511-515. Link: https://bit.ly/2JXjtIK

5. Hulsmann M, Hahn W (2000) Complications during root canal irrigation: literature review and case reports [review]. Int Endod J 33: 186-193. Link: https://bit.ly/3ou7JpF

6. Napte B, Srinidhi SR (2015) Endodontic Irrigants. J Dent Allied Sci 4: 25-30. Link: https://bit.ly/2VPViYQ

7. Glossary (1998) American Association of Endodontics. Contemporary terminology for endodontics. 6 th ed. Chicago.

8. Dakin HD (1925) On the use of certain antiseptic substances in the treatment of infected wounds. Br Med J 2: 318-320. Link: https://bit.ly/3qCuKbl

9. Estrela C, Estrela CR, Barbin EL, Spanó JC, Marchesan MA, et al. (2002) Mechanism of action of sodium hypochlorite. Braz Dent J 13: 113-117. Link: https://bit.ly/3qwBhou

10. Mistry KS, Shah S (2011) Review on common root canal irrigants. J Dent Sci 2 27-31. Link: https://bit.ly/33REVzv

11. Moorer WR, Wesselink PR (1982) Factors promoting the tissue dissolving capability of sodium hypochlorite. Int Endod J 15: 187-196. Link: https://bit.ly/3IK6bWU

12. Shabahang S, Torabinejad M (2003) Effect of MTAD on Enterococcusfaecaliscontaminated root canals of extracted human teeth. J Endod 29: 576-579. Link: https://bit.ly/3IR9POT

13. Sim TP, Knowles JC, Ng YL, Shelton J, Gulabivala K (2001) Effect of sodium hypochlorite on mechanical properties of dentine and tooth surface strain. Int Endod J 34: 120-132. Link: https://bit.ly/37IYZoS

14. Hülsmann M, Heckendorff M, Lennon A (2003) Chelating agents in root canal treatment: mode of action and indications for their use. Int Endod J 36: 810830. Link: https://bit.ly/360CwHD

15. Spencer NCO, Sunday JJ, Georgina OKEO, Agbor AA, Esosa US, et al. (2011) Comparative stabilizing effectsof some anticoagulants on fasting blood glucose of diabetics and non-diabetics, determined by spectrophotometry (glucose oxidase). Asian J Med Sci 3: 234-236. Link: https://bit.ly/3qA1LWc

16. Sayin TC, Serper A, Cehreli ZC, Otlu HG (2007) The effect of EDTA, EGTA, EDTAC, and tetracycline- $\mathrm{HCl}$ with and without subsequent $\mathrm{NaOCl}$ treatment on the microhardness of root canal dentin. Oral Surg Oral Med Oral Pathol Oral Radiol Endod 104: 418-424. Link: https://bit.ly/36Pphqa

17. Mistry KS, Shah S (2011) Review on common root canal irrigants. J Dent Sci 2. 27-31.

18. Ng YL, Mann V, Gulabivala K (2011) A prospective study of the factors affecting outcomes of nonsurgical root canal treatment: part 1: Periapical health. Int Endod J 44: 583- 609. Link: https://bit.ly/2JUDb1I

19. Dunavant TR, Regan JD, Glickmann GN, Solomon GS, Honeyman AL (2006) Comparative evaluation of endodontic irrigants against Enterococcus faecalis biofilms. J Endod 32: 527-531. Link: https://bit.ly/3oybTwC

20. Torabinejad M, ChoY, Khademi AA, Bakland LK, Shabahang S (2003) The effect of various concentrations of sodium hypochlorite on the ability of MTAD to remove the smear layer. J Endod 29: 233-239. Link: https://bit.ly/3ggLdhe

21. Haapsalo M, Endal U, Zandi H, Coil J (2005) Eradication of endodontic infection by instrumentation and irrigation solutions. Endodontic topics 10 77-102. Link: https://bit.ly/3INQFsZ
22. Endodontic Irrigants by David Carter,DMD.

23. Mohammadi Z, Abbott PV (2009) Antimicrobial substantivity of root canal irrigantsand medicaments: A review. Aust Endod J 35: 131-139. Link: https://bit.ly/2JzjNr7

24. Sceiza MF, Daniel RL, Santos EM, Jaeger MM (2001) Cytotoxic effects of $10 \%$ citric acid and EDTA-T used as root canal irrigants: An In vitro analysis. J Endod 7: 741-743. Link: https://bit.ly/36QbmQX

25. Moliz MT, Luque CM, García ME, Baca P (2009) Enterococcus faecalisbiofilms eradication by root canal irrigants. $\mathrm{J}$ Endod 35: 711-714. Link: https://bit.ly/2VJZOrR

26. Ballal NV, Kandian S, Mala K, Bhat KS (2009) Comparison of the efficacy of maleicacid and ethylenediaminetetraacetic acid in smear layer removal from instrumented human root canal: A Scanning Electron Microscopic Study. J Endod 35: 1573-1576. Link: https://bit.ly/2VJ9u6d

27. Ballal NV, Kandian M, Bhat KS (2010) Evaluation of the effect of maleic acid and EDTA on microhardness and surface roughness of human root canal dentin. J Endod 36: 1385-1388. Link: https://bit.ly/2Jy37jH

28. Asghar S, Ali A, Somoro S, Rashid S (2013) Antimicrobial solutions used for root canal disinfection. Pak Oral Dent $\mathrm{J}$ 33: 165-171. Link: https://bit.ly/3glvsFM

29. Valera MC, Chung $A$, Menezes MM, Fernandes $C E$, Carvalho $C A$, et al. (2010) Scanning electron microscope evaluation of chlorhexidine gel andliquid associated with sodium hypochlorite cleaning on the root canal walls. Oral Surg Oral Med Oral Pathol Oral Radiol Endod 110: e82-87. Link: https://bit.ly/33QjxuJ

30. Kandaswamy D, Venkateshbabu N (2010) Root canal irrigants. J Conserv Dent 13: 256-264. Link: https://bit.ly/39NSu6V

\section{Discover a bigger Impact and Visibility of your article publication with Peertechz Publications}

\section{Highlights}

* Signatory publisher of ORCID

* Signatory Publisher of DORA (San Francisco Declaration on Research Assessment)

* Articles archived in worlds' renowned service providers such as Portico, CNKI, AGRIS, TDNet, Base (Bielefeld University Library), CrossRef, Scilit, J-Gate etc.

* Journals indexed in ICMJE, SHERPA/ROMEO, Google Scholar etc.

* OAI-PMH (Open Archives Initiative Protocol for Metadata Harvesting)

* Dedicated Editorial Board for every journal

* Accurate and rapid peer-review process

* Increased citations of published articles through promotions

- Reduced timeline for article publication

Submit your articles and experience a new surge in publication services (https://www.peertechz.com/submission).

Peertechz journals wishes everlasting success in your every endeavours.

Copyright: $\odot 2020$ Kaur P. This is an open-access article distributed under the terms of the Creative Commons Attribution License, which permits unrestricted use distribution, and reproduction in any medium, provided the original author and source are credited. 